\title{
AKSES TERHADAP KEADILAN DAN PEMBERDAYAAN HUKUM SEBAGAI PENDEKATAN UNTUK PENGEMBANGAN HUKUM BAGI ORANG MISKIN DAN YANG TERPINGGIRKAN
}

\author{
Munir Salim \\ Fakultas Syariah dan Hukum Universitas Islam Negeri Alauddin Makassar
}

\begin{abstract}
Currently, strengthening law and government is the main focus of several international organizations, as well as governments and organizations at the national level. Reforms with a "justice and legal empowerment" approach can help support the poor and marginalized people in their quest to seek and obtain justice in their lives.
\end{abstract}

Keywords:

Justice, Empowerment, Law

\begin{abstract}
Abstrak
Saat ini, penguatan hukum dan pemerintahan menjadi fokus utama beberapa organisasi internasional, begitupun pemerintahan dan organisasi di tingkat nasional. Reformasi dengan pendekatan "keadilan dan pemberdayaan hukum" dihaapkan dapat mendukung masyarakat miskin dan orang-orang yang terpinggirkan dalam upaya mereka untuk mencari dan memperoleh keadilan dalam kehidupan mereka.
\end{abstract}

Kata Kunci:

Keadilan, Pemberdayaan, Hukum

\section{A. PENDAHULUAN}

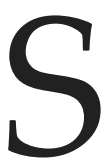

elama beberapa periode ini, penguatan hukum dan pemerintahan menjadi fokus utama dalam organisasi internasional, serta untuk pemerintahan dan organisasi di tingkat nasional. Saat ini organisasi tersebut telah mengeluarkan sebagian besar dana pembangunan ke dalam program peningkatan kapasitas yang ditujukan untuk hukum dan administratif lembaga di negara-negara transisi dan berkembang. Namun, 'pembangunan' sistem hukum dan pemerintahan terbukti menjadi tugas yang sangat sulit dan rumit. Diasumsikan bahwa hukum itu dan pemerintahan adalah masalah teknis, manajerial dan keuangan, yang memungkinkan untuk ekspor hukum dan transplantasi hukum serta struktur administrasi. Hasil mengecewakan ini dari reformasi semacam itu telah 
diilustrasikan, bagaimanapun, bahwa tidak cukup perhatian yang telah diberikan tentang bagaimana hukum, kebijakan, institusi, dan pemangku kepentingan, dalam konteks sosio-politik mereka. Keunikan dari masing-masing negara, sektor, dan institusi seringkali tidak dipahami dengan baik, dan yang sebenarnya adalah pengalaman terhadap program hukum dan tata kelola serta proyek-proyek yang tidak diterjemahkan ke dalam pengetahuan tentang bagaimana hukum dan pemerintahan terhadap pembangunan.

Menurut Leiden University Press tentang Hukum, Pemerintahan menyatukan sebuah badan kerja interdisipliner tentang pembentukan dan fungsi sistem hukum dan pemerintahan di negara berkembang, dan mengintervensi mereka. Ini bertujuan untuk melibatkan akademisi, pembuat kebijakan dan praktisi di tingkat nasional dan internasional, sehingga mencoba untuk merangsang hukum reformasi untuk pembangunan.

Reformasi dengan pendekatan "keadilan dan pemberdayaan hukum" guna mendukung masyarakat miskin dan orang-orang yang terpinggirkan dalam upaya mereka untuk mencari dan memperoleh keadilan dalam kehidupan mereka. Pergeseran dari reformasi kelembagaan top-down ke bottom-up sebagai intervensi yang menginformasikan fokus baru pada akses terhadap keadilan dan strategi baru dalam pemberdayaan hukum.

Upaya kerjasama pembangunan hukum secara tradisional berusaha untuk mempromosikan "Aturan Hukum" melalui reformasi hukum dan penguatan kelembagaan (terutama dari lembaga peradilan). Sementara akses terhadap keadilan menjadi bagian dari program ini, itu bukan tujuan utama mereka. Pergeseran dari reformasi kelembagaan top-down ke bottom-up intervensi menginformasikan fokus baru pada akses terhadap keadilan dan strategi baru pemberdayaan hukum.

\section{B. PEMBAHASAN: AKSES KEADILAN DAN REFORMASI PEMBERDAYAAN HUKUM - DELAPAN PERTIMBANGAN KEBIJAKAN \\ 1. Pemberdayaan Hukum Dan Akses Terhadap Keadilan Merupakan Area Yang Sensitif Terhadap Batasan Politik}

Banyak sarjana setuju dengan Golub (2003: 6) ketika dia menulis: "Banyak orang di negara berkembang, hukum yang menguntungkan orang miskin ada di atas kertas tetapi tidak dalam prakteknya kecuali orang miskin atau sekutunya mendorong penegakan hukum".

Hubungan kekuasaan yang tidak setara melemahkan kemampuan orang miskin untuk melakukan aktifitas dan melindungi hak mereka, untuk mengakses layanan dan institusi, dan untuk berpartisipasi dalam proses ekonomi, politik dan sosial. Para sarjana sekarang setuju bahwa reformasi lebih berhasil ketika mereka dilengkapi dengan upaya untuk mengatasi struktur kekuasaan asimetris. Dengan kesadaran yang meningkat dan peningkatan kapasitas, orang miskin dan kelompok masyarakat itu mendukung mereka lebih berkualitas untuk mengatasi hubungan 
kekuasaan yang tidak setara, baik di dalam maupun di luar sistem hukum (Cotula, 2007).

Isu sensitif asimetri kekuasaan memunculkan pertanyaan rumit. Siapa yang harus diberdayakan? Kekuatan siapa yang harus dibatasi? Sejauh mana dapat atau seharusnya seorang aktor asing melakukan intervensi di lokal dan struktur kekuatan nasional? Bagaimana dengan kedaulatan negara? Pertanyaan-pertanyaan ini akan menjadi lebih tajam ketika asimetri kekuasaan secara langsung melibatkan rezim otoriter.

\section{Fokus Konseptual Pada Penyelesaian Sengketa Yang Mengabaikan Beberapa Keluhan}

Bagi para akademisi, pembuat kebijakan dan praktisi mengukur akses ke keadilan dengan sejauh mana orang dapat mencari dan memperoleh solusi terhadap keluhan hukum melalui mekanisme negara. "Kerangka konseptual yang komprehensif tentang akses ke keadilan dan pemberdayaan hukum perlu berfokus secara eksplisit pada keduanya untuk mencegah keluhan hukum dan mendapatkan ganti rugi yang melawan mereka. Fokus untuk mendapatkan solusi terhadap keluhan tampaknya diabaikan, paling tidak pada tingkat konseptual, pentingnya mencegah keluhan yang berkembang di tempat pertama: misalnya, pencegahan pelanggaran hak individu di kantor polisi dan pusat penahanan, dimana tempat tersebut adalah tempat yang memadai untuk pengaduan layanan publik dan pemerintahan tanpa korupsi. Kerangka konseptual yang komprehensif tentang akses ke keadilan dan pemberdayaan hukum perlu difokuskan secara eksplisit pada pencegahan keluhan dan mendapatkan ganti rugi terhadap mereka. Untungnya, secara praktek, upaya yang ditujukan untuk mencegah keluhan, seperti hak asasi manusia terhadap pendidikan dan sensitisasi, sering menjadi bagian dari akses ke program peradilan dan pemberdayaan hukum.

\section{Reformasi Harus Mengatasi Keadilan Negara Dan Hukum Adat}

Sebagian besar bantuan pembangunan selama bertahun-tahun telah dialokasikan berdasarkan sistem hukum. Meskipun dalam upaya ini orang miskin dan terpinggirkan di banyak negara berkembang terus mengalami kesulitan besar untuk mengakses sistem hukum negara: itu jauh, lambat, mahal, bias, tidak dapat diandalkan, dan seterusnya. Karena mekanisme peradilan secara adat secara harfiah tersedia "di depan pintu orang-orang", mereka menangani mayoritas sengketa, khususnya di daerah pedesaan. Mereka dianggap cepat, murah dan lebih disesuaikan dengan keadaan, misalnya, karena mereka mempromosikan rekonsiliasi di antara orang-orang tersebut. Dalam situasi konflik dan pasca-konflik, mekanisme adat ini mungkin satu-satunya fora tersedia untuk menyelesaikan perselisihan dengan cara damai. Komunitas ini telah mulai menyadari bahwa akses terhadap reformasi peradilan seharusnya juga termasuk sistem peradilan adat.

"Penelitian di Indonesia dan Ghana menunjukkan hal itu dalam banyak kasus orang lebih memilih untuk menyelesaikan perselisihan dan klaim mereka hak 
mereka melalui cara damai, disuatu waktu mereka lebih suka membawa kasus mereka ke pengadilan negara untuk mendapatkan keputusan yang otoritatif atau lebih adil".

Fakta bahwa sebagian besar kasus ditangani adat tidak berarti mereka memberikan akses "optimal" ke pengadilan. Orang miskin dan terpinggirkan mungkin memiliki akses, tetapi terkadang diragukan mereka mendapatkan keadilan. Pertama-tama, penegakan keputusan tidak dijamin karena tekanan sosial yang telah terkikis dari waktu ke waktu. Forum adat juga dikenal diskriminatif terhadap perempuan, migran dan para pemuda, kurang transparansi dan akuntabilitas, dan menjadi rentan terhadap penangkapan kaum elit. Terkadang merendahkan mereka dan member hukuman keras (kopral). Oleh karena itu para donor menganjurkan reformasi sistem adat untuk berfungsi sesuai dengan standar hak asasi manusia internasional. Faktor yang lebih rumit dalam sistem hukum adat adalah koeksistensi versi kontes hukum adat dalam suatu komunitas. Tidak selalu jelas siapa yang menentukan aturan mana yang harus diterapkan. Penelitian di Indonesia dan Ghana telah menunjukkan bahwa meskipun sebagian besar kasus orang lebih suka menyelesaikan perselisihan mereka dan mengklaim hak mereka melalui cara konsiliatori, kadang-kadang, mereka lebih suka mengambil kasus mereka ke pengadilan negara bagian untuk mendapatkan keputusan yang otoritatif atau lebih adil (World Bank, 2004 \& Crook, 2007). Apalagi, "bayangan negara hukum dan sistem peradilan negara "cenderung memperkuat alternatif, mekanisme penyelesaian perselisihan; kemungkinan salah satunya pihak-pihak dapat membawa masalah ini ke pengadilan yang kemungkinan akan mendorong pihak-pihak menyelesaikan kasus sebelum mereka harus menghadapi sanksi pengadilan. Mendukung reformasi dari sistem hukum negara tetaplah penting. Negara hukum dan adat memuji satu sama lain; keduanya diminta untuk memberikan akses keadilan kepada orang miskin dan kelompok terpinggirkan di masyarakat.

Keadilan Desa di Indonesia. Studi Kasus tentang Akses ke Keadilan, Demokrasi dan Pemerintahan Desa Sumber: Bank Dunia (2004: IV-V).

Temuan utama studi kasus tentang korupsi dalam proyek pembangunan desa. "Penduduk desa dan pemimpin desa lebih suka menyelesaikan sengketa secara informal. Beberapa pertimbangan menginformasikan preferensi ini. Pertama, mereka anggap mekanisme informal menjadi lebih murah, lebih cepat dan lebih mudah digunakan daripada sistem hukum formal. Waktu, jarak dan biaya sangat serius menjadi hambatan di daerah pedesaan di mana, di satu tempat, penduduk desa membutuhkan waktu selama tiga hari dan setara dengan setengah upah bulanan minimum untuk bepergian ke ibukota kabupaten untuk diwawancarai oleh polisi. Kedua, warga desa merasakan negosiasi informal menjadi tidak mengganggu secara sosial daripada menggunakan hukum sistem. Penekanan mereka pada harmoni sebagian besar mencerminkan realitas kehidupan desa, di mana orang-orang dikenal dan bergantung satu sama lain, tetapi itu juga mencerminkan ketakutan akan balas 
dendam dan - bagi para pemimpin desa - sebuah keinginan untuk mempertahankan status quo dan menghindari pengawasan eksternal. Akhirnya, penduduk desa hanya tahu sedikit tentang hukum, tidak mempercayainya dan menganggapnya terlalu jauh dari kendali mereka. Meskipun lebih suka menyelesaikan masalah secara informal, masyarakat desa tidak menggunakan lembaga desa yang ada di Indonesia untuk kasus-kasus di mana ada ketidakseimbangan kekuatan besar antara para pihak. Lembaga desa dalam hal ini tidak memadai dalam kasus di mana para pelaku adalah pejabat pemerintah atau memiliki hubungan dekat dengan mereka. Hasil dari ketidakseimbangan ini, para pelaku tidak takut sanksi sosial atau tidak menerima ancaman sanksi hukum secara serius. Dalam beberapa kasus tanpa ketidakseimbangan ini, masyarakat desa bisa menyelesaikannya masalah secara informal. Mereka mampu melakukannya melalui mobilisasi tekanan sosial dan politik dan dengan menggunakan ancaman sanksi hukum untuk meningkatkan kekuatan tawar-menawar secara informal kepada mereka.

Meskipun masyarakat desa lebih suka menyelesaikan masalah secara informal dan menyadari kelemahan sistem hukum yang terkenal, mereka bersedia menggunakan sistem hukum sebagai upaya terakhir untuk bertahan pada kepentingan mereka dalam kasus-kasus di mana lembaga desa mereka yang ada telah gagal. Akses penduduk desa ke sistem hukum cenderung bergantung pada apakah mereka memiliki fasilitator dengan tautan ke LSM, pemerintah lokal atau struktur manajemen proyek pembangunan desa. Fasilitator seperti itu menyediakan akses ke informasi, membantu komunitas kepada pemimpin dengan pengorganisasian keterampilan dan pemimpin terkait dengan kelompok masyarakat sipil yang mampu memantau kinerja sistem hukum.

Secara keseluruhan, sistem hukum mampu mengatasi kekuatan lokal yang tidak seimbangan untuk menjatuhkan sanksi kepada para pelaku korupsi. Kasuskasus itu mengatur preseden berharga terhadap korupsi dan membantu membangun kepercayaan masyarakat terhadap institusi hukum. Namun, eksekusi keputusan pengadilan itu bermasalah. Tak satu pun dari kasus yang pergi ke pengadilan itu putusan pengadilan dilaksanakan sepenuhnya. Komunikasi yang buruk kembali ke masyarakat dari hasil tindakan hukum juga mengurangi dampak dari preseden positif. Ini membuat mereka enggan menggunakan sistem hukum di masa depan untuk kasus serupa".

\section{Baik Negara Maupun Masyarakat Sipil Harus Memainkan Peran}

Akses terhadap keadilan dan pemberdayaan hukum sering kali meliputi kerja sama dengan organisasi masyarakat sipil seperti LSM. Dengan melibatkan masyarakat sipil, reformasi lebih mampu menjangkau kelompok miskin dan terpinggirkan. Terlibatnya masyarakat sipil juga memungkinkan donor untuk melaksanakan program di luar sistem hukum negara.

Dalam memilih untuk bekerja sama dengan masyarakat sipil, beberapa pertimbangan perlu diingat. Kadang-kadang sulit untuk membedakan dengan jelas 
antara "negara" dan "masyarakat sipil"; batas-batas kabur sementara (dis) koneksi mungkin tidak terlihat. Pertimbangan lain adalah apakah fokus pada organisasi masyarakat sipil harus menghalangi keterlibatan dengan negara institusi. Berdasarkan pengalamannya bekerja untuk Ford Foundation dan ADB, Golub, konsultan terkemuka untuk pemberdayaan hukum, advokat membatasi kerjasama terutama untuk organisasi masyarakat sipil. Dia menyatakan (2006: 168): “Layanan hukum yang paling sukses dan kreatif untuk orang miskin di seluruh dunia umumnya dilakukan oleh LSM, seringkali dalam kemitraan dengan organisasi komunitas, atau kadang-kadang oleh program sekolah hukum yang berfungsi secara efektif sebagai LSM. "Meskipun tidak menghalangi peran negara, pendekatan Golub terhadap pertanyaan-pertanyaan pemberdayaan hukum nilainya adalah: "Meskipun ada niat terbaik dari banyak personel (negara bagian) seperti itu, berbagai aktor dan faktor, paling tidak rekan kerja mereka, dapat memblokir mereka melakukan pekerjaannya dengan benar. Pertimbangan terkait yang menggagalkan tanggapan pemerintah terhadap kebutuhan hukum dan kebutuhan orang miskin lainnya termasuk alokasi sumber daya yang tidak tepat, birokrasi yang berlebihan, korupsi, patronase, bias jender, dan penolakan umum untuk berubah. "Golub Oleh karena itu, pendekatan pemberdayaan hukum tidak berfokus pada reformasi lembaga negara, yang ditemukan hanya akan menguntungkan elit.

5. Akses Terhadap Keadilan Dan Pemberdayaan Hukum Dalam Kasus Pidana Harus Mencakup Korban Dan Terdakwa

Dalam akses ke keadilan dan pemberdayaan hukum, kasus pidana menempati posisi yang berbeda dari kasus-kasus non-pidana. Karakteristik utama kasus kriminal adalah bahwa negara memiliki monopoli atas penuntutan kejahatan. Dalam kasus pidana ringan, mekanisme peradilan adat mungkin tersedia di samping lembaga negara. Tetapi lebih banyak lagi kasus serius, kejaksaan monopoli negara mewajibkan korban untuk beralih ke lembaga negara, polisi atau layanan kejaksaan. Korban mungkin menghadapi petugas yang tidak kompeten, backlog, korupsi, dll. Hambatan yang dapat diatasi dengan akses ke keadilan dan pemberdayaan hukum. Akses ke keadilan dan pemberdayaan hukum dalam peradilan pidana sistem terkait dugaan pelaku kejahatan (terdakwa) juga sebagai korban. Selama bertahun-tahun, reformasi terfokus pada penyediaan bantuan hukum gratis untuk terdakwa. Di sini konsep akses terhadap keadilan adalah terkait erat dengan standar hak asasi manusia internasional untuk terdakwa dan terpidana: mis. hak atas proses hukum, hak untuk adil didalam pengadilan, hak atas bantuan hukum (gratis). Pendekatan alternatif dalam bidang pemberdayaan hukum saat ini sedang dieksplorasi, misalnya penggunaan "paralegal komunitas" di penjara yang memberi tahu tahanan menunggu persidangan tentang prosedur dan hak mereka, dan memantau mereka kasus (Penal Reform International, 2007). 


\section{Menetapkan Tujuan Realistis, Prioritas, Dan Koordinasi Mencegah Kekecewaan}

Mempromosikan pemberdayaan hukum dan meningkatkan akses ke keadilan sangat besar tujuannya. Kelompok sasaran (yang berpotensial) sangat luas dan beragam, sangat menarik dengan relasi kekuasaan adalah tugas yang sulit dan reformasi perlu ditangani proses dan institusi yang saling terkait secara bersamaan.

"Akses terhadap keadilan dan pemberdayaan hukum juga merupakan sarana untuk mencapai tujuan lain seperti pengurangan kemiskinan, menjamin hak individu, kepastian hukum, keamanan terhadap kejahatan dan penyalahgunaan wewenang pemerintah, dan reformasi hukum serta prosedur hukum. "

Tujuan dan prioritas yang realistis harus ditetapkan untuk mencegah kekecewaan dan kritik. Sementara akses terhadap keadilan dan pemberdayaan hukum berakhir dalam diri mereka sendiri, mereka juga sarana untuk mencapai tujuan lain seperti pengurangan kemiskinan, jaminan individu hak, kepastian hukum, keamanan terhadap kejahatan dan pemerintah penyalahgunaan, dan reformasi hukum dan prosedur hukum (Hammergren, 2007). Pilihan strategis perlu dibuat dan dibuat secara eksplisit: tujuan mana yang realistis dan mendapatkan prioritas, masalah apa yang perlu ditujukan untuk mencapai tujuan ini, dan segmen mana yang miskin dan terpinggirkan orang akan didukung. Donor yang bekerja di nasional dan regional pengaturan juga perlu mengkoordinasikan upaya mereka sehingga tujuan yang lebih besar dapat dicapai. Tugas harus dibagi melalui harmonisasi donor, sesuai dengan prioritas, keahlian, dan sumber daya kebijakan masing-masing donor. Titik masuk dan urutannya adalah konteks yang saling terkait. Sementara ada konsensus bahwa akses ke keadilan dan reformasi pemberdayaan hukum harus holistik dalam menangani lembaga dan proses yang berbeda pada saat yang sama, keterbatasan waktu dan sumber daya membutuhkan strategi keputusan tentang titik masuk dan pendekatan yang akan diambil: misalnya, perspektif penyedia keadilan atau pencari keadilan.

Ketika pemrograman untuk akses ke keadilan dan pemberdayaan hukum, pertanyaan yang muncul apakah orang mendapat manfaat dari akses ke tidak kompeten dan sistem yang tidak adil. Tetapi sebagai pendukung penegakan hukum menekankan, tuntutan yang lebih baik dan lebih efektif untuk layanan peradilan dapat terjadi menyebabkan tanggapan positif dari penyedia keadilan. Ini argumen untuk memasuki reformasi dengan memungkinkan pencari keadilan menyuarakan tuntutan mereka.

\section{Titik Masuk Dan Urutannya Adalah Konteks Yang Terkait}

Sementara ada konsensus bahwa akses ke keadilan dan reformasi pemberdayaan hukum harus holistik dalam menangani lembaga dan proses yang berbeda pada saat yang sama, keterbatasan waktu dan sumber daya membutuhkan strategi keputusan tentang titik masuk dan pendekatan yang akan diambil: misalnya, perspektif penyedia keadilan atau pencari keadilan. 
Ketika pemrograman untuk akses ke keadilan dan pemberdayaan hukum, yang memunculkan pertanyaan apakah orang mendapat manfaat dari akses ke tidak kompeten dan sistem yang tidak adil. Tetapi sebagai pendukung penegakan hukum menekankan, tuntutan yang lebih baik dan lebih efektif untuk layanan peradilan dapat terjadi menyebabkan tanggapan positif dari penyedia keadilan. Ini merupakan argumen untuk memasuki reformasi dengan memungkinkan pencari keadilan menyuarakan tuntutan mereka.

Pendekatan ini, bagaimanapun, mengandung risiko bahwa penyedia keadilan akan gagal menanggapinya. Ketika ini atau menjadi jelas, pencari keadilan kemungkinan akan menahan diri dari mencari akses ke penyedia keadilan ini.

"Keterbatasan waktu dan sumber daya membutuhkan keputusan strategis mengenai titik masuk dan pendekatan yang akan diambil: misalnya, perspektif penyedia keadilan atau pencari keadilan".

Faktor-faktor lain ketika memutuskan titik masuk dan urutannya adalah ketersediaan sumber daya dan jangka waktu. Beberapa rintangan lebih mudah untuk menghapus dari yang lain tetapi membutuhkan dana besar: misalnya, Keterbatasan keuangan seseorang dapat diselesaikan dengan membuat skema untuk bantuan hukum.

Hambatan lain, seperti pengadilan yang bias atau stigma budaya terikat untuk mengejar tindakan hukum, lebih kompleks dan membutuhkan pembeda dan pendekatan jangka panjang. Karena program reformasi sangat bergantung pada konteks, "satu ukuran untuk semua" solusi tidak mungkin menghasilkan hasil yang diinginkan. Ada, namun, studi kasus dan laporan yang menunjukkan bagaimana titik masuk tertentu dan metode pengurutan telah berhasil dalam situasi tertentu: misalnya, pada pemberdayaan hukum kelompok lokal terhadap investor asing (Cotula, 2007), pada layanan paralegal (Maru, 2006), tentang bantuan hukum untuk terdakwa (Reformasi Pidana Internasional, 2007) dan sistem peradilan adat (Penal Reform International, 2001). Membimbing pertanyaan ketika memutuskan poin masuk dan urutan sequencing termasuk: Hasil apa yang dapat diperoleh dari memilih titik entri tertentu? Siapa yang akan mendapat manfaat? Bagaimana titik masuk tertentu akan mempengaruhi lainnya langkah-langkah dalam proses mengakses keadilan?

\section{Mengukur Hasil Dan Dampak Merupakan Elemen Yang Sangat Penting}

Seperti intervensi kerjasama dalam pembangunan hukum lainnya, proyek dan program untuk mendukung akses terhadap keadilan dan kecenderungan pemberdayaan hukum untuk mengevaluasi output daripada hasil dan dampaknya. Sarjana hukum dan ekonomi yang telah mencoba mengukur biaya keadilan (dalam hal uang, waktu, penundaan dan biaya emosional), dan kualitasnya, telah menemui berbagai kesulitan (Barendrecht, 2006). Evaluasi hasil dan dampak sering tidak dilakukan karena sulitnya mengembangkan indikator dan alat ukur lainnya, sementara evaluasi sendiri sangat mahal dan memakan waktu. Sebagai akibatnya, 
kita hanya tahu sedikit tentang efek sebenarnya dari akses terhadap keadilan atau program pemberdayaan hukum. Pentingnya kuantitatif data meskipun (misalnya, pada berapa banyak orang telah menggunakan pengadilan, lamanya periode penahanan pra-ajudikasi), data keluaran secara umum tidak menjelaskan apakah kekhawatiran orang telah ditanggapi atau apakah ketimpangan telah dikurangi (Hammergren, 2007 \& Van Rooij, 2007). Ini bermasalah karena memunculkan apakah intervensi ini memang cara terbaik yang tersedia untuk memenuhi kebutuhan miskin dan terpinggirkan. Karena itu penting untuk menginvestasikan waktu dan uang dalam mengembangkan alat untuk mengukur hasil dan dampak akses ke keadilan dan program pemberdayaan hukum. Informasi empiris seperti itu akan memungkinkan strategi dan perancangan yang lebih baik intervensi yang lebih tepat untuk mengatasi kebutuhan dan ketidakadilan yang sebenarnya dihadapi oleh orang miskin.

\section{PENUTUP}

\section{Kesimpulan}

Akses Keadilan dan Reformasi Pemberdayaan Hukum - Delapan Pertimbangan Kebijakan, yakni :

a. Pemberdayaan Hukum Dan Akses Terhadap Keadilan Merupakan Area Yang Sensitif Terhadap Batasan Politik

b. Fokus Konseptual Pada Penyelesaian Sengketa Yang Mengabaikan Beberapa Keluhan

c. Reformasi Harus Mengatasi Keadilan Negara Dan Hukum Adat

d. Baik Negara Maupun Masyarakat Sipil Harus Memainkan Peran

e. Akses Terhadap Keadilan Dan Pemberdayaan Hukum Dalam Kasus Pidana Harus Mencakup Korban Dan Terdakwa

f. Menetapkan Tujuan Realistis, Prioritas, Dan Koordinasi Mencegah Kekecewaan

g. Titik Masuk Dan Urutannya Adalah Konteks Yang Terkait

h. Mengukur Hasil Dan Dampak Merupakan Elemen Yang Sangat Penting

\section{Saran}

Untuk para penegak hukum, harus berlaku adil kepada masyarakat, baik yang menengah atas ataupun menengah bawah karena tiap warga negara berhak untuk mendapatkan keadilan hukum. 


\section{Daftar Pustaka}

Cotula, Lorenzo (2007), Legal Empowerment for Local Resource Control: Securing Local Resource Rights within Foreign Investment Projects in Africa,London: IIED.

Golub, Stephen (2003), Beyond Rule of Law Orthodoxy. The Legal Empowerment Alternative, Washington D.C.: Carnegie Endowment for International Peace.

Golub, Stephen (2006) 'The Legal Empowerment Alternative', in: Th. Carothers (ed.), Promoting the Rule of Law Abroad. In Search of Knowledge, 161 - 187, Washington D.C.: Carnegie Endowment for International Peace.

Hammergren, Linn (2007), Envisioning Reform. Improving Judicial Performance in Latin America, University Park, PA: Penn State University Press.

Maru, Vivek (2006), 'Between Law and Society: Paralegals and the Provision of Justice Services in Sierra Leone and Worldwide', The Yale Journal of International Law 31: 427 - 476.

Penal Reform International (2001), Access to Justice in Sub-Sahara Africa. The role of traditional and informal justice systems. London: Penal Reform International. Penal Reform International and the Bluhm Legal Clinic of the Northwestern

Van Rooij, Benjamin (2007), Bringing Justice to the Poor: Bottom-Up Legal Development Cooperation, Occasional Paper, Leiden: Van Vollenhoven Institute.

World Bank.World Bank (2004), Village Justice in Indonesia: Case Studies on Access to Justice, Village Democracy \& Governance. Jakarta: World Bank.

World Bank, Justice for the Poor, http://go.worldbank.org/IMMQE3ET20. 